This article is (C) Emerald Group Publishing and permission has been granted for this version to appear here (https://dspace.lib.cranfield.ac.uk/index.jsp).

Emerald does not grant permission for this article to be further copied/distributed or hosted elsewhere without the express permission from Emerald Group Publishing Limited. www.emeraldinsight.com

\title{
Servant Leadership in the People's Republic of China: A Case Study of the
} Public Sector

\author{
Dr. Yong Han \\ Department of Public Administrative Education and Research \\ Guangxi College of Administration \\ No. 18 Libin Avenue, \\ Nanning, P.R. China, 530021 \\ E-mail: y.han@hotmail.co.uk
}

\author{
Prof. Nada K. Kakabadse \\ Professor in Management and Business Research \\ Northampton Business School \\ The University of Northampton \\ Park Campus, Boughton Green Road \\ Northampton, NN2 7AL, UK \\ Email: Nada.Kakabadse@northampton.ac.uk
}

and

Prof. Andrew Kakabadse

Professor of International Management Development

Cranfield School of Management

Cranfield, Beds, MK43 OAL, United Kingdom

International Tel: (0044) (0)1234 754400

International Fax: (0044) (0)1234 752382

E-mail: a.p.kakabadse@cranfield.ac.uk 


\title{
Servant Leadership in the People's Republic of China: A Case Study of the Public Sector
}

\begin{abstract}
Purpose - This paper explores whether the Western concept of servant leadership holds the same meaning in the public sector of the cross-cultural context of China and identify whether there is an alternative term in the Chinese language that closely relates to the concept of servant leadership
\end{abstract}

Design/methodology/approach - An inductive approach is adopted based on critical incident technique, using open-ended survey to collect the data.

Findings-We found that the concept of servant leadership holds parallel meaning in China, to that of the West and that we can describe the Chinese concept of servant leadership precisely as public servant leadership in the public sector and servant leadership in the non-public sector. We also report that when asked to characterize Chinese servant leadership in the public sector, the study respondents consider six types of servant leadership similar to the West but also three types of Chinese extended servant leadership.

Originality/value - The paper is a first attempt to examine servant leadership in the public sector in China. It not only reports various forms of Chinese servant leadership orientation, but also compares and contrasts various servant leadership forms between China and the West, highlighting research gaps for future research within the context of the People's Republic of China (PRC) and the West. 
Keywords: Servant leadership, public sector, People's Republic of China (PRC).

Paper type: Research paper

With the shadow of corporate scandals such as Enron and Worldcom, Tyco, and other companies in the United States and globally, scholars pointed out that certain styles of leadership and management practices including "bullying leadership, abusive leadership, unethical practices, toxic emotions, social isolation and alienation in the workplace, and the violation of employees' psychological well-being and work-life balance" may contribute to these negative phenomena in the organization (Sendjaya et al, 2008, p.402). Therefore, in order to help restore employees' trust, commitment and confidence in management, scholars view servant leadership as one avenue to achieving such a goal (Farling et al., 1999; Page and Wong, 2000; Patterson et al., 2003; Winston, 2004; Winston and Ryan, 2007; Sendjaya, 2003; Sendjaya et al, 2008). In addition, organizations are competing in a global environment and are under pressure to attract and retain high-performing employees. Thus for both governance and talent management purposes, the concept of servant leadership is at the core of drawing, keeping and motivating high performance employees (Fry et al., 2007). Moreover, Pfeffer (2003) proposes that it is a leader's responsibility to help one's employees to strike a balance between their spiritual world and their working roles. Hence, scholars consider servant leadership as an effective management practice in 
helping an organization to compete with others in the context of globalization and creating a balance for employees' external work and inner life (Fry et al., 2007).

Although scholars have discussed and described servant leadership almost entirely in the American context (Winston and Ryan, 2008), overall commentators have not given sufficient attention to exploring servant leadership in other cultural contexts.

In addressing this research gap, this paper explores the relevance of servant leadership as applied to the public sector in the People's Republic of China (PRC). In this study, we ask: Would the concept of servant leadership have the same meaning in China, or, is there an alternative term in the Chinese language that closely relates to the concept of servant leadership? How do people construe the notion of servant leadership in the public sector of the PRC? To address these questions, this paper first provides a comprehensive review of the extant literature on servant leadership in the West and in China respectively. Then, this study reports the results of an inductive research approach to investigate servant leadership in public sector in the Chinese context 


\section{Servant Leadership: Its Definition, Nature and Dimensions}

Greenleaf (1970) an influential advocate of the servant as leader described the phenomenon as; "It [servant leadership] begins with the natural feeling that one wants to serve. Then conscious choice brings one to aspire to lead. The difference manifests itself in the care the servant takes - first to ensure that other people's highest priority needs are served. The best test is: Do those served grow as persons; do they, while being served, become healthier, wiser, freer, more autonomous, and more likely themselves to become servants?" (p. 4) Servant leadership puts and promotes followers' interest in the first place (Barbuto and Wheeler, 2006; Greenleaf, 1977). Servant leaders encourage followers to intelligently grow, be creative, self-manage and serve people. This leads to the betterment of society and advocates acceptance, tolerance, empathy, love, forgiveness, and adherence to the Golden Rule of "do unto others as you shall have them do unto you". Fry et al. (2007, p.6) summarized this definition as "the servant-leader is servant-first, an attitude that flows from a deep-rooted, natural inclination to serve [followers]" at work.

Excluding conceptual papers (Page and Wong, 2000; Patterson et al., 2003; Winston, 2004; Winston and Ryan, 2007) and Laub's (1999) empirical operationalization of the servant organization, but based on empirical validation of servant leadership from Barbuto and Wheeler (2006), Dennis and Bocarnea (2005), Dennis and Winston 
(2003), Ehrhart (2004), Liden et al. (2008) as well as Sendjaya (2003; 2008), this paper identifies the following dimensions of servant leadership in the extant North American literature ( see Table 1 for an illustration):

Table 1 about here

\section{Leadership Styles in the PRC Context}

Having examined various forms of servant leadership in the West, Winston and Ryan (2008) suggests that the Global Leadership and Organizational Behavior Effectiveness Research Program's (GLOBE) humane orientation construct shows the idea of servant leadership embedded in cultural concepts, ranging from African (Ubuntu, Harambee); East Asian (Daoist, Confucianism); Mediterranean (Jewish); and Indian (Hindu) value systems. However, a review of the extant literature identifies three major driving forces for the formulation of Chinese Servant leadership: Confucianism (Snell and Tseng, 2003; Winston and Ryan, 2007), Daoism (Johnson, 2000; Kakabadse et al., 2002; Winston and Ryan, 2007) and Communist ideology (Fu and Tsui, 2003; Snell and Tseng, 2003). 


\section{Confucianism}

$\mathrm{Fu}$ and Tsui (2003, p.427) suggested the relevance of Confucian virtues in affecting Chinese leadership as following:

- The class system-"Wu lun" (five cardinal relationships), particularly determined by courtesy;

- Obedience — respect to seniors, officers; reliable/dependable; loyalty/faithfulness

- Doctrine of the mean-moderation; tolerance; forgiveness, wisdom; avoid extremes;

- The Chinese term, Renqing — benevolence, righteousness.

Also, Cheung and Chan (2008) suggested that magnanimity and sensitivity to other people (including subordinates), keeping promises and justice are the virtues of Confucian leadership. Moreover, with specific reference to servant leadership, Winston and Ryan (2008) and Yuan (2002) also added morality, love, altruism, kindness, charity, compassion, goodness, perfect virtue, true selfhood, benefiting others as Confucian servant leadership style.

Last, but not least, Han and Altman (2009) reported that positive features in supervisor-subordinate guanxi leadership include perceived supervisor support care and protection, recognition of subordinates, interactional justice, the quality of the supervisor-subordinate relationship outside work, the quality of the supervisor's 
positive attributes and subordinate's positive attributes, all of whichoverlap with the idea of servant leadership.

In terms of trust and empowerment, critical elements of Western servant leadership, there are no studies that indicate it is inclusive or exclusive in Chinese servant leadership. Wong et al. (2003) findings on trust in the supervisor and Zhang et al.'s (2007) study of empowerment, showed that trust in supervisor and empowerment are relatively independent constructs from other organizational and leadership variables.

\section{Daoism}

Daoist leadership with an emphasis on conformity to the "dao" or "the way" has evolved over the past 2,500 years, with its creator, Lao $\mathrm{Zi}$, being a contemporary of Confucius (Cheung and Chan, 2008). The extant literature suggests that in relation to servant leadership, Daoist servant leadership includes the following characters or behaviors: vision, embracing insight and wisdom; serving the community (Kakabadse et al., 2002); maintaining a low profile (i.e., humility), leading by example, and empowering people through ownership of the task to do the work (Johnson, 2000; Winston and Ryan, 2007).

\section{Communist Ideology}


According to the Chinese Communist Party Constitution (1997) summarized by Fu and Tsui (2003, p.427), Communist leadership should display the following characteristics:

- Willingness to serve the people whole-heartedly, even at the expense of themselves;

- Devotion to the realization of communist moral education;

- Hard work;

- Belief in and reliance on people;

- Placement of collective interests in front of self interests;

- Abiding by Party policies and state laws and maintenance of unity;

- Loyalty and honesty to the Party;

- Resistance against corruption;

- Promotion of Communist moral codes, and readiness to sacrifice one's life at times of difficulty and danger.

Although the term of servant leadership may not be mentioned explicitly in the Chinese communist context, its concept is not new. Even after economic reforms, Chinese schools, organizations, and society at large are characterized by active programs promoting public service-oriented government=Lei Feng (1940-1962), a role model in the People's Liberation army, exemplified the official work values of the model Chinese Communist employee by behaviors such as "carrying strangers' heavy loads, washing colleagues' clothes as they slept, and on one occasion, giving away his own packed lunch" (Snell and Tseng, 2003, p.314). The teachings of Lei Feng include: "Xue Lei Feng, shu xin feng' (Emulate Lei Feng, establishing a new practice, 'Xuexi Lei Feng, shuli gongchanzhuyi lixiang' (Emulate Lei Feng, establishing Communist ideals), and 'Xuexi Lei Feng haobangyang_fayang jianku fendoude jingsheng' (Study Lei Feng's fine example-develop the spirit for better 
struggle)" (Snell and Tseng, 2003, p.314). With such values in mind Snell and Tseng (2003) commented that the spirit of Lei Feng's writing is similar to the idea of servant leadership.

Since China's open door policy, together with its economic reforms, of the last two decades, the drive for organisational efficiency and effectiveness, and global competitiveness over the last two decades has propelled managerial reform and organizational reinvention, which has impacted in the Chinese public sector. In 1982, the Party launched a socialist spiritual civilization construction program aimed at “ instilling straight and clean thinking, cultural participation, orderliness, tidiness, and good manners" "through ideological exhortation, re-education and thought reform." This still remains a prominent Party program and a criterion in the performance appraisal of state civil servants (Snell and Tseng, 2003, p.314). Thus, the promotion of the socialist spiritual civilization construction program, is coincidentally akin to Greenleaf's (1977) servant leaders (Snell and Tseng, 2003).

In the 17th National Congress, President Hu Jintao recently declared the importance of developing a public service-oriented government. President Hu Jintao has called for: "the government to improve its service to the people" and he proposed that "a fair, capable and sustainable public service will help build a harmonious society". "The 
ultimate goal of building a service-oriented government is to enhance the government's capability and level of service" and "the key points in strengthening public services are ensuring and improving people's livelihoods" with the "government's obligation to provide fast, convenient and high quality services for citizens." As a result, "the quality of public services will become a crucial standard in evaluating government work" (Xinhua News, 2008). Such initiatives for public service quality enhancement foster the development of servant leadership in Chinese public sector management.

We have just discussed the extant literature on servant leadership in the West and the cultural roots for Chinese, servant leadership, in particular in contemporary China. In addition, as one of the fastest developing economies in the world, China is both of theoretical and practical importance to understand whether servant leadership is a relevant and/or critical concept. If servant leadership is not an applicable concept within the context of China and its developments, then we question whether it may be applicable elsewhere and whether scholars should reconfigure it as a Western construct, thereby embedding this significant aspect of leadership style in a Western discourse. Additionally, "a potential criticism of servant leadership is that it focuses solely on the individual needs of employees, which may or may not benefit the organization" (Fry et al., 2007, p.2). Thus, servant leadership may be a more natural 
model for application in the public sector than in the private sector due to the public sector's not-for-profit and service orientation.

Nevertheless, irrespective of previous inquiry into the Chinese leadership phenomena, scholars as yet know little of whether the concept of servant leadership has the same meaning in China or whether there is an alternative term in the Chinese language that closely relates to the concept of servant leadership (Cheung and Chan, 2008). Towards this end, this paper provides empirical data about public sector people's perceptions on servant leadership in their particular workplace and with reference to specific events. The exploratory nature of this research required that an inductive approach be adopted as the research method.

\section{Research Method}

\section{Pilot Survey}

\section{Sample, Procedures and Results}

The pilot survey reported here explores whether the concept of servant leadership has the same meaning in China as it does in the West, or whether there is an alternative Chinese term that closely relates to the concept of servant leadership. Towards this end, a semi structured interview format was adopted whereby this study collected concrete examples of servant leadership in the Chinese public sector where this study used Chinese term(s) for servant leadership. 
Pilot survey consisted of interviewing four Chinese senior civil servants and four Chinese employees from the non-public sector in a new economically booming coastal city in South China. Fifty percent male, the group had an average age of 35 and 6 years work experience respectively,

The authors of this paper used interviews as the main data collection method in eliciting responses. After presenting the summarized servant leadership concept as "the servant-leader is servant-first, an attitude that flows from a deep-rooted, natural inclination to serve [followers]" at work (Fry et al., 2007, p.6), the interviewer asked the informants whether this concept has the same meaning in China or if there is an alternative term in the Chinese language that closely relates to this concept.

The first author (a native Chinese) interviewed each of the participants individually. The results showed that all informants contended that the concept of servant leadership has the same meaning in China. Furthermore, this study found that the Chinese concept of servant leadership may be precisely described as public servant leadership in the public sector, whilst servant leadership in non-public sector.

\section{Main Study}

\section{Samples and Procedures}

In the Chinese context, public sector organizations refer to "central governmental agencies, state, county, municipal, and township governmental units, and 
quasi-governmental enterprises"(Lan et al., 2009). The sample for the main study consisted of 99 informants from 34 different organizations (see Figure 1) in the same new economically booming city in South China as in pilot survey.

Figure 1 about here

This study used an open-ended questionnaire survey as our data collection method, but this time based on a critical incident technique. We asked the participants to describe one or more concrete events that they viewed as servant leadership in their work experience, in line with Flanagan's (1954) critical incident technique. Flanagan defines a critical incident as any observable human activity that is "sufficiently complete in itself to permit inferences and prediction to be made about the person performing the act" (Flanagan, 1954, p. 327). We justify this method as follows. Compared with interviews or focus groups or observations (typical qualitative methods), open-ended questionnaire surveys may "offer greater anonymity to respondents and often elicit more honest responses". They may "capture diversity in responses and provide alternative explanations to those that closed-ended survey questions are able to capture" (Jackson and Trochim, 2002, p.307). They "force respondents to express themselves more concisely while at the same time giving them opportunity to vent or explain themselves in a shorter narrative form." Answers may "vary from a few phrases to a couple of paragraphs and represent a wide variety of concepts with varying frequency and detail a 'free list in context type of text" (Jackson and Trochim, 2002, 
p.308). In a Chinese organizational research context, this paper considers this approach more appropriate than drawing on other qualitative data collection methods such as interview and observation due to the cultural-social-political context of contemporary China, whereby identifying the respondents for interview or the lack of external behavioral clues for observation may jeopardize the collection of the high quality data. Of course, this approach may yield incomplete answers and raise concerns on the issue of the reliability of coding decisions, but no methodology is immune from deficiencies. We predicate this approach on the precedence set by a number of key scholars in their studies of China: Farh, Zhong and Organ, 2004 (organizational citizenship behavior); Tsui, Wang and Xin, 2006 (organizational culture); and Liu, Spector and Jex, 2006 (job strain). We asked the respondents," "According to your past experience and knowledge, please give example(s) of public servant leadership at work.." To avoid potentially biasing their responses, the researchers did not provide the respondents with examples.

The first researcher conducted all of the interviews. Altogether, 99 participants provided a response rate of $80 \%$. This is a higher than normal response rate for an organization-based survey in social sciences (Baruch, 1999). Table 2 indicates, the percentage of respondents' gender, age, and educational qualifications. Among the respondents, $68 \%$ were male and $26 \%$ were female. The predominant age group was 31-40 years (ranging from 33 to 56 years old). 
Table 2 about here

The first researcher (a native Chinese) assessed all critical incidents on two criteria: a) the answer must have a clear meaning in the Chinese language; and b) the answer must refer to leadership incidents. The researcher rejected any ambiguous or difficult to interpret answers. Overall, in 133 collected incidents, 116 were relevant and valid. Then, the data, in its Chinese version, was submitted to semiotic cluster analysis (Eco, 1976; Feldman, 1995). Semiotic clustering is a simple, yet powerful technique that allows researchers to uncover successive levels of meaning, from surface signs to the underlying structure (Manning, 1987, Cunha, 2004). In this process, we used the data-driven code development of Thematic Analysis (Boyatzis, 1998) in analyzing our data. This process includes identification of themes and development of codes and clusters. We began with "reducing the raw information, identifying themes within sub-samples, comparing themes across sub-samples, creating a code (book), and determining the reliability (of the code)" (Boyatzis, 1998, p.44).

To test the reliability of the codes (Miles and Huberman, 1994) deduced by the first author of this paper (Coder 1), a second coder (Coder 2: a native Chinese) labeled the data by adopting the nine categories developed by Coder 1 . The two coders compared 
and discussed their results and finally agreed on a common format ${ }^{1}$. Finally, they employed quasi-statistical methods to transform textual data into quantitative data, focusing upon overall frequencies and descriptive statistics, rather than significance testing (King, 1994).

\section{Results}

In our approach to semiotic cluster analysis, we tabulated the qualitative data into three columns. Table 3 presents the semiotic clustering for this study on different categories of servant leadership in the public sector in China. Table 4 describes the frequencies and descriptive statistics in different categories of each type of servant leadership.

Table 3 about here

Table 4 about here

The first column in Table 3 refers to signs or denotative meanings. It is often labeled 'competing meanings' (Feldman, 1995) or 'denotative meanings' (Strauss and Corbin,

\footnotetext{
${ }^{1}$ The interrater reliability score between the first researcher and the first data auditor for the nine the competing meaning is $87 \%$, for the connotative meaning is $100 \%$ and for the institutional concern is $100 \%$.
} 
1990) and includes the main ways in which the study participants have approached the target concept (See Table 5 for illustrative examples). In their answers to our questions, the respondents described nine types of leadership as servant leadership in the public sector of China (See first column in Table 3). Table 4 describes the percentage of incidents in different categories. Of the 116 incidents, nine competing meanings emerged throughout the content analysis. These are: putting people first (32\%), being dutiful (19\%), ethical behavior (13\%), moral (agapao) love (12\%), leadership (conceptual) skills (11\%), humility (4\%), building relationship(3\%), devotion to Party policies and state laws (3\%), and listening (3\%) (See Table 4).

Table 5 about here

The second column in Table 3 of our semiotic cluster analysis, 'connotative meanings', shows "a pattern in the denotative meanings and builds new meaning through some type of association between competing or denotative meanings" (Cuhna, 2004, p.131). "There is not a 'right' way of filling in this column since the meanings are dependent upon interpretation and emerge from data" (Strauss and Corbin, 1990 in Cuhna, 2004, p.131). We grouped these into two 'connotative meanings' (See second column in Table 3.) i.e. similar group and different group respectively, which suggest the possible similarities and differences between Western and Chinese perceptions on servant leadership. The 'similar' group of servant leadership (75\% in total) in our semiotic cluster analysis suggested putting people first, ethical behavior, moral 
(agapao) love, leadership (conceptual) skills, humility and building relationships as common types of servant leadership behavior in China and in the West. However, being dutiful, complying with Party policies and state laws, and listening fell into the 'different' category ( $25 \%$ in total) of connotative meanings in our semiotic cluster analysis. We used the terms of similar and different in describing our servant leadership forms for ease of discussion since it is not reasonable to propose that a construct explored in two highly divergent cultures is unique (Farh et al., 2006). This paper describes these in detail in the next section.

\section{Similar Servant Leadership Types}

The most important servant leadership type in China, is putting people first $(32 \%$ out of 116 incidents). This more humane style uses actions and words to clearly indicate to others (especially immediate followers) that satisfying their work needs is a priority, particularly in assisting subordinates with problems they are facing with their assigned duties (Dennis and Bocarnea, 2005; Dennis and Winston, 2003; Ehrhart, 2004; Liden et al., 2008, Sendjaya, 2003; 2008)..

The second similar servant leadership type is ethical behavior, i.e. interacting openly, fairly, and honestly with employees and/or maintaining consistency between words and deeds (Ehrhart, 2004; Liden et al., 2008; Sendjaya, 2003; 2008). This Chinese 
type of servant leadership includes uncorrupted behavior and requires high levels of self-discipline.

The third similar servant leadership type is moral (agapao) love, genuinely caring for others, showing sensitivity to others' personal concerns and interest in the lives of followers (Barbuto and Wheeler, 2000; Dennis and Bocarnea, 2005; Liden et al., 2008). Slightly different from the Western servant leadership style, the Chinese servant leadership may also call for caring for disadvantaged groups or employees.

The fourth similar servant leadership type is conceptual skills, possessing the knowledge of the organization and the tasks at hand so as to be in a position to effectively support and assist others, especially immediate followers (Ehrhart, 2004; Liden et al., 2008). This includes the Western servant leadership type of wisdom, i.e. ability to seek pathways through challenging concerns, and vision, i.e., a leader's ability to anticipate the future and its consequences (Barbuto and Wheeler, 2006). Nevertheless, it does not include communicating shared vision to subordinates in the Western servant leadership type of wisdom or vision. 
The fifth servant leadership type is humility i.e., "acting quietly without deliberately seeking public attention (Sendjaya, 2003, p.4; 2008, p.407). The Chinese leadership type equivalent does not include showing respect for employees and acknowledging their contribution to the team (Dennis and Bocarnea, 2005).

The final similar servant leadership type is building relationship, the act of making a genuine effort to know, understand, and support others in the organization and outside the organization, with an emphasis on building long-term relationships with those people (Dennis and Bocarnea, 2005; Ehrhart, 2004). The Chinese type of servant leadership may have a broader view than the Western one since it also includes forming relationships with people outside the organization.

\section{Specific Chinese Servant Leadership}

We also found three types of servant leadership, which may be specific to the Chinese context including: being dutiful, displaying devotion to Party policies and state laws, and listening.

The first specific type is being dutiful, which shows that Chinese servant leaders are diligent, reliable and take the initiative at work. The second specific type is devotion 
and displaying devotion to Party policies and state laws, which is consistent with the requirement from the Chinese Communist Party Constitution (1997). The final type is listening, namely leaders' willingness to hear and value employees' opinions, ideas, and suggestions.

The last column in Table 3 of our semiotic cluster analysis involves a leap that is similar to the one that allows the transposition of data from the first (competing or denotative meanings) to the second column (connotative meanings). This column is labeled 'institutional concerns' and suggests a structure underlying the data which are meaningful servant leadership styles in China's public sector.

However, the authors did not find the Western perceptions on servant leadership styles of creating value for the community (Liden et al., 2008; see also Barbuto and Wheeler, 2006; Ehrhart, 2004); empowering (Liden et al., 2008; Dennis and Winston, 2003; Dennis and Bocarnea, 2005; Ehrhart, 2004; Sendjaya, 2003; 2008); persuasive mapping (Barbuto and Wheeler, 2006); and transcendent spirituality (Sendjaya, 2003; 2008) in our study.

\section{Conclusion}

Using an inductive approach to explore the term and content domain of servant leadership in the public sector in China, this study has shown that the concept of 
servant leadership holds comparable meaning in China. Furthermore, this study found that the Chinese concept of servant leadership has similar meaning in both the public and non-public sectors, whilst they used different words to describe it. Public servant leadership was used to describe servant leadership in public sector, whilst servant leadership was applied to non-public sector. This research shows that respondents characterized Chinese servant leadership in the public sector as such: putting people first, being dutiful, ethical behavior, moral (agapao) love, leadership (conceptual) skills, humility, relationship building, compliance with Party policies and state laws, and listening.

Overall, our study suggests that components of Confucianism, Daoism and Communist ideology influence the development and formulation of Chinese servant leadership. Our findings on the similar types of servant leadership between China and the West raise the following questions. First, why does Chinese servant leadership include uncorrupted and /or self-disciplined behavior as behaving ethically? We consider this to be the result of the Chinese educational systems' promotion of the Chinese Communist Party Constitution (1997) summarized by Fu and Tsui (2003, p.427), including resistance against corruption and abidance of Party policies and state laws. Second, why does Chinese servant leadership of moral (agapao) love include caring for the disadvantaged group or employees? This type of behavior may broadly include assistance for disadvantaged employees, such as the laid-off, the sick, and the retiree, as well as assistance for employees with personal difficulties. This 
indicates the Chinese leadership style of renqing-benevolence and righteousness in the findings from Fu and Tsui (2003).

Third, do Chinese leaders need to communicate shared vision to subordinates as revealed by servant leadership of wisdom or vision (Barbuto and Wheeler, 2006; Dennis and Bocarnea, 2005; Dennis and Winston, 2003; Sendjaya, 2003; 2008)? We suggest the following possible interpretation: communicating shared vision to subordinates is part of a leader's daily work, otherwise they would not easily achieve organizational missions and goals. Finally, do Chinese leaders need to show respect for employees and acknowledge their contribution to the team through adopting a humility servant leadership style (Dennis and Bocarnea, 2005, p.603)? The extant literature has shown that in terms of supervisor-subordinate guanxi, Chinese leaders do need to show respect towards employees and acknowledge their contribution to the team (Han and Altman, 2009). However, in Han and Altman's (2008) study, these types of behavior are identified as recognition of subordinates a phenomenon viewed as distinctly Chinese and not an aspect of servant leadership.

Turning our attention to specific forms of Chinese servant leadership, we view being dutiful as an extended Chinese form of servant leadership. Duty is often regarded as a conservative and perhaps even an outdated concept. The organizational behaviour 
literature rarely mentions the concept of duty/devotion, yet changes in the social and organizational environments have made a sense of duty ever more necessary. We often equate duty with obligation, but in fact much of this behavior is volitional. When organizational dysfunctions appear, important tasks may be left undone, and unexpected problems may arise for which there is no standardized solution. Hence, organizations need people, particularly leaders who, through their discretionary action, ensure that their team, department or organization continue to function not only efficiently, but as one organic whole.

Furthermore, listening may be a so-called type of Chinese servant leadership since Western scholars mention this type of behavior, but do not fully explore its meaning within the Chinese context (Barbuto and Wheeler, 2006; Spears, 1995). Finally, devotion to Party policies and state laws is a requirement of the Chinese Communist Party Constitution (1997), and is a uniquely salient influence on Chinese leaders, particularly in the public sector.

\section{Limitations, Future Research Directions and Managerial Suggestions}

Although this study covers a spectrum of contemporary public sector Chinese organizations, our sample is not representative of all Chinese organizations in the pubic sector. Our analysis does not preclude different interpretations in other settings since this research does not cover entire meanings of servant leadership in Chinese societies. Another limitation of this research is that since we asked for perceptions on 
servant leadership, more than $85 \%$ of respondents provided illustrations by proxy in reference to others or abstract incidents in the organization rather than servant leadership between themselves and their supervisors. Because of this, the authors were unable to compare dyadic leadership between managerial civil servants and non-managerial civil servants and precisely compare servant leadership perceptions across gender. This calls for further research. Future research may also explore what society may construe as servant leadership in business settings and compare and contrast such perceptional differences with people from the public sector.

In terms of implication for practice, this paper proposes the following: putting people first, being dutiful, ethical behavour, moral (agapao) love, leadership (conceptual) skills, humility, building relationship, devotion to Party policies and state laws, and listening are the ways which managers attract, retain and motivate their employees in the public sector in China. The concept of servant leadership in the PRC is to draw, keep and motivate high performance employees and that in order to restore employee's trust, commitment and confidence in management, servant leadership is a powerful philosophy and practice towards achieving such a goal. 
Table 1 Various Dimensions and Definitions of Servant Leadership

in the Western Literature

\begin{tabular}{|c|c|}
\hline Dimensions & Definition \\
\hline Agapao (i.e. love) & $\begin{array}{l}\text { genuinely caring for others, showing sensitivity to others' } \\
\text { personal concerns and interest in the lives of } \\
\text { followers (Dennis and Bocarnea, 2005; Barbuto and Wheeler, } \\
\text { 2000; see also Liden et al., } 2008 \text { for emotional healing). }\end{array}$ \\
\hline $\begin{array}{l}\text { Creating value for } \\
\text { the community }\end{array}$ & $\begin{array}{l}\text { "a conscious, genuine concern for helping the community" } \\
\text { (Liden et al., 2008, p. 162; see also Barbuto and Wheeler, } \\
2006 \text { for organizational stewardship; Ehrhart, 2004). }\end{array}$ \\
\hline Conceptual skills & $\begin{array}{l}\text { "possessing the knowledge of the organization and tasks at } \\
\text { hand so as to be in a position to effectively support and assist } \\
\text { others, especially immediate followers" (Liden et al., 2008, p. } \\
\text { 162; see also Ehrhart, 2004). }\end{array}$ \\
\hline Empowering & $\begin{array}{l}\text { "encouraging and facilitating others, especially immediate } \\
\text { followers, in identifying and solving problems, as well as } \\
\text { determining when and how to complete work tasks" (Liden et } \\
\text { al., 2008, p. 162; see also Dennis and Bocarnea, 2005; Dennis } \\
\text { and Winston, 2003; Ehrhart, 2004; Sendjaya, 2003; 2008). }\end{array}$ \\
\hline $\begin{array}{l}\text { Helping } \\
\text { subordinates grow } \\
\text { and succeed }\end{array}$ & $\begin{array}{l}\text { "demonstrating genuine concern for others' career growth } \\
\text { and development by providing support and mentoring" (Liden } \\
\text { et al., 2008, p. 162; see also Ehrhart, 2004; Sendjaya, 2003; } \\
2008 \text { for modeling and mentoring). }\end{array}$ \\
\hline $\begin{array}{c}\text { Putting subordinates } \\
\text { first }\end{array}$ & $\begin{array}{l}\text { "using actions and words to make it clear to others (especially } \\
\text { immediate followers) that satisfying their work needs is a } \\
\text { priority (Supervisors who practice this principle will often } \\
\text { break from their own work to assist subordinates with } \\
\text { problems they are facing with their assigned duties)" (Liden et } \\
\text { al., 2008, p. 162; see also Dennis and Winston, } 2003 \text { for } \\
\text { service; Dennis and Bocarnea, 2005; Ehrhart, 2004; Sendjaya, } \\
2003 \text {; } 2008 \text { for voluntary subordination). }\end{array}$ \\
\hline Ethical Behavior & $\begin{array}{l}\text { "interacting openly, fairly, and honestly with others" (Liden et } \\
\text { al., 2008, p. 162; see also Ehrhart, 2004; Sendjaya, 2003; } 2008 \\
\text { for responsible morality) and/or maintaining consistency } \\
\text { between words and deeds (Sendjaya, 2003; 2008). }\end{array}$ \\
\hline Wisdom or Vision & $\begin{array}{l}\text { "an ability to anticipate the future and its consequences" } \\
\text { (Barbuto and Wheeler, 2006, p. 308) and communicating this } \\
\text { shared vision to subordinates (Dennis and Winston, 2003; see } \\
\text { also Dennis and Bocarnea, 2005; Sendjaya, 2003; } 2008 \text { for }\end{array}$ \\
\hline
\end{tabular}




\begin{tabular}{|c|l|}
\hline & vision). \\
\hline Persuasive mapping & $\begin{array}{l}\text { "an ability to influence others by means outside of formal } \\
\text { authority" (Barbuto and Wheeler, 2006, p. 307). }\end{array}$ \\
\hline $\begin{array}{c}\text { Relationship } \\
\text { building with } \\
\text { subordinates }\end{array}$ & $\begin{array}{l}\text { the act of making a genuine effort to know, understand, and } \\
\text { support others in the organization, with an emphasis on } \\
\text { building long-term relationships with immediate followers } \\
\text { (Ehrhart, 2004; Dennis and Bocarnea, 2005). }\end{array}$ \\
\hline Trust & $\begin{array}{l}\text { "confidence in or reliance on another team member in terms of } \\
\text { their morality (e.g. honesty) and competence" (Dennis and } \\
\text { Bocarnea, 2005, p.603; see also Sendjaya, 2003; 2008). }\end{array}$ \\
\hline Humility & $\begin{array}{l}\text { "showing respect for employees and acknowledging their } \\
\text { contribution to the team (Dennis and Bocarnea, 2005, p.603) } \\
\text { and "act quietly without deliberately seeking public attention } \\
\text { (Sendjaya, 2003, p.4; 2008, p.407) }\end{array}$ \\
\hline $\begin{array}{l}\text { Transcendent } \\
\text { spirituality }\end{array}$ & $\begin{array}{l}\text { bringing together "service and meaning - the leader is attuned } \\
\text { including colleagues, the organization, and society" (Fry, } \\
\text { 2003, p. 708 cited in Sendjaya, 2008, p.407) and "restoring a } \\
\text { sense of wholeness (Conger, 1994; Hicks, 2002 cited in } \\
\text { Sendjaya, 2008, p.407) and fostering a 'holistic, integrated } \\
\text { life" "(Fairholm, 1997, p. 31 cited in Sendjaya, 2008, p.407). }\end{array}$ \\
\hline
\end{tabular}


Table 2: Respondents Gender, Age and Positions

\begin{tabular}{|l|c|}
\hline Demographic Variables & Distribution (in percentage) \\
\hline Gender & \\
\hline Male & \\
\hline Female & $68 \%$ \\
\hline Missing information & $24 \%$ \\
\hline Age & $8 \%$ \\
\hline $21-30$ & \\
\hline $31-40$ & $8 \%$ \\
\hline $41-50$ & $29 \%$ \\
\hline $51-60$ & $45 \%$ \\
\hline Missing information & $10 \%$ \\
\hline Positions & $8 \%$ \\
\hline Managerial & \\
\hline Non-managerial & \\
\hline Missing information & \\
\hline & \\
\hline & \\
\hline & \\
\hline & \\
\hline & \\
\hline & \\
\hline & \\
\hline & \\
\hline & \\
\hline & \\
\hline & \\
\hline & \\
\hline & \\
\hline & \\
\hline
\end{tabular}


Table 3: Semiotic Cluster Analysis of the Qualitative Data

\begin{tabular}{|c|c|c|}
\hline $\begin{array}{c}\text { Competing meanings } \\
\text { (Chinese servant leadership } \\
\text { means...) }\end{array}$ & $\begin{array}{c}\text { Connotative meanings } \\
\text { (Chinese servant } \\
\text { leadership can...) }\end{array}$ & $\begin{array}{c}\text { Institutional concerns } \\
\text { (Chinese servant leadership } \\
\text { is...) }\end{array}$ \\
\hline Putting people first & $\begin{array}{l}\text { Be similar to Western } \\
\text { servant leadership. }\end{array}$ & Meaningful \\
\hline Ethical behaviour & $\begin{array}{l}\text { Be similar to Western } \\
\text { servant leadership. }\end{array}$ & Meaningful \\
\hline Moral (agapao) love & $\begin{array}{l}\text { Be similar to Western } \\
\text { servant leadership. }\end{array}$ & Meaningful \\
\hline Leadership (conceptual) skills & $\begin{array}{l}\text { Be similar to Western } \\
\text { servant leadership. }\end{array}$ & Meaningful \\
\hline Humility & $\begin{array}{l}\text { Be similar to Western } \\
\text { servant leadership. }\end{array}$ & Meaningful \\
\hline Building relationships & $\begin{array}{l}\text { Be similar to Western } \\
\text { servant leadership. }\end{array}$ & Meaningful \\
\hline Being dutiful & $\begin{array}{c}\text { Be different from Western } \\
\text { servant leadership. }\end{array}$ & Meaningful \\
\hline $\begin{array}{c}\text { Devotion to Party policies } \\
\text { and state laws }\end{array}$ & $\begin{array}{c}\text { Be different from Western } \\
\text { servant leadership. }\end{array}$ & Meaningful \\
\hline Listening & $\begin{array}{c}\text { Be different from Western } \\
\text { servant leadership. }\end{array}$ & Meaningful \\
\hline
\end{tabular}


Table 4:Quasi-statistical of Semiotic Cluster Analysis of the Qualitative Data

\begin{tabular}{|l|c|c|}
\hline \multicolumn{1}{|c|}{$\begin{array}{c}\text { Chinese Servant } \\
\text { Leadership }\end{array}$} & Percentage \\
\hline $\begin{array}{l}\text { Similar Servant } \\
\text { Leadership (75\% } \\
\text { in total) }\end{array}$ & \\
\hline & Putting people first & $32 \%$ \\
\hline & Ethical behaviour & $13 \%$ \\
\hline & Moral (agapao) love & $12 \%$ \\
\hline & $\begin{array}{c}\text { Leadership } \\
\text { (conceptual) skills }\end{array}$ & $11 \%$ \\
\hline & Humility & $4 \%$ \\
\hline & Building relationships & $3 \%$ \\
\hline $\begin{array}{l}\text { Different Servant } \\
\text { Leadership } \mathbf{( 2 5 \%} \\
\text { in total) }\end{array}$ & Being dutiful & $19 \%$ \\
\hline \multicolumn{2}{|c|}{$\begin{array}{c}\text { Devotion to Party } \\
\text { policies and state laws }\end{array}$} & $3 \%$ \\
\hline & Listening & $3 \%$ \\
\hline
\end{tabular}


Table 5: Types of Chinese Servant Leadership and Illustrative Examples

\begin{tabular}{|c|c|}
\hline Types of Servant Leadership & Illustrative Examples of Behavioral or Character Attributes \\
\hline Putting people first & $\begin{array}{l}\text { Putting people first } \\
\text { Working for people's interests. } \\
\text { Exercising power for the people } \\
\text { Serving people wholeheartedly }\end{array}$ \\
\hline Ethical behaviour & \begin{tabular}{|l} 
Integrity \\
Fairness \\
Justice \\
Self-discipline \\
Selflessness
\end{tabular} \\
\hline Moral (agapao) love & $\begin{array}{l}\text { Showing concern for the people } \\
\text { Caring about subordinates } \\
\text { Help solve problems when needed } \\
\text { Caring for disadvantaged groups } \\
\text { Caring about people's interests }\end{array}$ \\
\hline Leadership (conceptual) skills & $\begin{array}{l}\text { Knowledgeable } \\
\text { Creative } \\
\text { Have an ability to lead and organize }\end{array}$ \\
\hline Building relationships & $\begin{array}{l}\text { Having good interpersonal relationship with people at all levels } \\
\text { Dealing with the relationship properly within and outside the } \\
\text { organization }\end{array}$ \\
\hline Humility & $\begin{array}{l}\text { Sociable } \\
\text { Friendly }\end{array}$ \\
\hline Being dutiful & $\begin{array}{l}\text { Being committed to one's work } \\
\text { Having a strong sense of responsibility } \\
\text { Being serious with one's work } \\
\text { Working hard }\end{array}$ \\
\hline Devotion to Party policies and state laws & $\begin{array}{l}\text { Being loyal to the enforcement of Party Policy } \\
\text { Complying with state laws and regulations }\end{array}$ \\
\hline Listening & $\begin{array}{l}\text { Listening to the people } \\
\text { Accepting people's ideas }\end{array}$ \\
\hline
\end{tabular}


Figure 1 List of Organizations

Commission of Economy

Educational Office

Scientific and Technological Office

Commission of Ethnic Groups

Police Office

Bureau of Taxation

Office of Inspection

Office of Civil Administration

Office of Jurisdiction

Office of Public Finance

Office of Personnel

Office of Labour and Social Insurance

Office of National Land and Resources

Office of Construction

Office of Communications

Office of Water Conservancy

Office of Agriculture

Office of Business

Office of Health

Office of Auditing

Office of Foreign Affairs

Office of Industrial and Business Administration

\section{References:}

Barbuto, J. E. and Wheeler, D. W. (2006). "Scale development and construct clarification of servant leadership". Group and Organization Management, Vol. 


\section{1, pp.300-326}

Baruch, Y. (1999), "Response rate in academic studies - A comparative analysis", Human Relations, Vol. 52, pp.421-438.

Boyatzis, R. (1998). Transforming Qualitative Information: Thematic Analysis and Code Development. Sage Publications, Thousand Oaks, CA.

Cameron, K. , Dutton, J. \& Quinn, R, (1998). (eds.), Positive Organizational Scholarship. San Francisco: Berrett-Koehler Publishers, Inc., pp. 163-175

Cheung, C and Chan, A.C (2008). "Benefits of Hong Kong Chinese CEOs' Confucian and Daoist leadership styles", Leadership and Organization Development Journal, Vol. 29 No. 6, pp. 474-503

Cunha, M.P.E. (2004, "In search of organizational cockaigne: Identifying the pillars of the ideal organization", Journal of Management, Spirituality and Religion, Vol.1, pp.77-92.

Dennis, R. S. and Bocarnea, M. (2005) "Development of the servant leadership assessment instrument." Leadership and Organization Development Journal, Vol.26, pp.600-615

Dennis, R., and Winston, B. (2003). “A factor analysis of page and wong's servant leadership instrument: From items to factors". Leadership and Organizational Development Journal. Vol. 24, pp. 455-459.

Eco, U (1976), A Theory of Semiotics, Bloomington, University of Indiana Press.

Ehrhart, M. G. (2004). "Leadership and procedural justice climate as antecedents of unit-level organizational citizenship behavior”. Personnel Psychology, Vol.57, 61-94.

Farling, M, Stone, A. G., and Winston, B. E. (1999). "Servant leadership: Setting the stage for empirical research". The Journal of Leadership Studies. Vol. 6, No.1/2 pp.49-72

Farh, J. L., Zhong, C. B., and Organ, D. W. (2004). "Organizational citizenship behaviour in the People's Republic of China”. Organization Science. Vol. 15, pp.241-253

Farh, J. L., Cannella, A.A. Jr., and Lee, C. (2006). “Approaches to scale development in Chinese management research". Management and Organization Review, Vol. 
2, pp.301-318.

Feldman, M.S. (1995), Strategies for Interpreting Qualitative Data, Sage, Thousand Oaks, CA.

Flanagan, J. C.(1954), "The critical incident technique", Psychological Bulletin, Vol.51, pp.327-358.

Fry, L.W. , Matherly, L. L., Whittington, J. L. and Winston, B. E. (2007). "Spiritual leadership as an integrating paradigm for servant leadership". In Singh-Sengupta, S., and Fields, D. (Eds.).Integrating Spirituality and Organizational Leadership, Macmillan Ltd., India, pp.70-82.

Fu, P. P. and Tsui, A. (2003) "Utilizing media to understand desired leadership attributes in the People's Republic of China". Asia Pacific Journal of Management, Vol. 20, pp.423-446.

Greenleaf, R. (1970). The servant as leader. Indianapolis: The Robert K. Greenleaf Center, 1-37

Greenleaf, R. K. (1977). Servant Leadership: A Journey into the Nature of Legitimate Power and Greatness. Paulist Press, New York.

Han, Y. and Altman, Y. (2009) "Supervisor-subordinate guanxi: A grounded investigation in in the People's Republic of China", Journal of Business Ethics, Vol. 88, pp.91-104

Jackson, K. M. and Trochim, W. M. K. (2002). "Concept mapping as an alternative approach for the analysis of open-ended survey responses", Organizational Research Methods_Vol._5, pp.307-336.

Johnson, C. (2000). “Taoist leadership ethics". Journal of Leadership Studies, Vol. 7, pp. 82-91.

Kakabadse, A., Kakabadse, N. and Kouzmin, A., (2002), "Spirituality and leadership praxis", Journal of Managerial Psychology, Vol. 17, No. 3, pp. 165-182.

King, N. (1994). 'The qualitative research interview". In Cassell, C. and Symon, G. (Eds), Qualitative Methods in Organizational Research: A Practical Guide. Sage, Thousand Oaks, CA

Lan, G. Z., Galaskiewicz, J. and Xu, X (2009) "Special issue on 'Innovations in Public and Non-profit Sector Organizations in China'", Management and 
Organization Review, Vol. 5, pp.163-164

Laub, J. A. (1999). Assessing the servant organization: development of the organizational leadership assessment (OLA) instrument. Florida Atlantic University, Boca Raton, FL. Florida Atlantic University164 pages; AAT 9921922

Liden, R. C., Wayne, S. J., Zhao, H. and Henderson, D. (2008). "Servant leadership: Development of a multidimensional measure and multi-level assessment". The Leadership Quarterly, Vol. 19, pp.161-177

Liu, C., Spector, P. E., and Jex, S. (2006), "The relation of job control with job strains: A comparison of multiple data sources". Journal of Occupational and Organizational Psychology, Vol.78, pp.325-336.

Manning, P.K. (1987), Semiotics and Fieldwork, Sage, Thousand Oaks.

Miles, M. B. and Huberman, A. M. (1994). Qualitative Data Analysis: An Expanded Sourcebook, 2nd edition. Sage, Thousand Oaks, CA.

Page, D., and Wong, T.P. (2000). A conceptual framework for measuring servant-leadership. In S.B.-S.K. Adjiboloss (Ed.), The Human Factor in Shaping the Course of History and Development. Rowan and Littlefield, Lanham, MD.

Patterson, K., Redmer, T. A. O., and Stone, G. A. (2003). Transformational leaders to servant leaders versus level 4 leaders to level 5 leaders: The move from good to great. Paper presented at the CBFA Annual Conference, Virginia Beach, VA

Pfeffer, J. (2003). Business and the spirit. In R. A. Giacalone, and C. L. Jurkiewicz (eds.), Handbook of Workplace Spirituality and Organizational Performance (pp. 29-45).

Sendjaya, S (2003). Development and validation of servant leadership behavior scale. Regent University Servant Leadership Roundtable Proceedings, available at http://www.regent.edu/acad/global/publications/sl_proceedings/2003/sendjaya_d evelopment_validation.pdf (accessed 20 February 2009).

Sendjaya, S., Sarros, J. C. and Santora, J. C. (2008) "Defining and measuring servant leadership behaviour in organizations", Journal of Management Studies Vol. 45, pp.402-424

Snell, R.S and Tseng, C, S. (2003), "Images of the virtuous employee in China's transitional economy", Asia Pacific Journal of Management, Vol.20, pp.307-331 
Spears, L. (1995), "Servant-leadership and the Greenleaf legacy", Reflections on Leadership: How Robert K. Greenleaf's Theory of Servant-leadership Influenced Today's Top Management Thinkers, John Wiley \& Sons, New York, NY, pp.1-14.

Strauss, A. and Corbin, J. (1990), Basics of Qualitative Research: Grounded Theory Procedures and Techniques. Sage, Newbury Park, CA.

Tsui, A.S., Wang, H., and Xin, K.R. (2006), "Organizational culture in the PRC: An analysis of culture dimensions and culture types". Management and Organization Review, Vol. 2, pp.345-376.

Winston, B. (2004) "Heritage Bible College: A case study in servant leadership and servant followership". Leadership and Organizational Development Journal, Vol. 25, pp.600-617

Winston, B. and Ryan, B. (2007) "Servant leadership as a humane orientation: Using the GLOBE study construct of humane orientation to show that servant leadership is more global than western", International Journal of Leadership Studies, Vol.11 pp.45-49

Wong, Y.T., Wong, C.S., and Ngo, H.Y. (2003). "Antecedents and outcomes of employees' trust in Chinese joint ventures", Asia Pacific Journal of Management, Vol. 20, pp.481-499.

Xinhua News (2008), President Hu calls for service-oriented government. Available at http://www.news.xinhuanet.com/english/2008-02/24/content 7665292.htm (accessed 20 February 2009).

Yuan, L. (2002). "Ethics of care and concept of jen: A reply to Chenyang Li". Hypati, Vol. 17, pp.107-129.

Zhang, Y., Chen, C., and Wang, H. (2007). Bounded empowerment: Main and joint effects of supervisory power sharing and management control. Paper presented at the Annual Meeting of Academy of Management, Ontario, August 2007 